\title{
A new paradigm of industrial system optimization based on the conception "Industry 4.0"
}

\author{
Olga Maksimchuk ${ }^{1}$, and Tatyana Pershina ${ }^{1, *}$ \\ ${ }^{1}$ The department of management and urban development and construction, Volgograd State Technical University, Volgograd, Russia
}

\begin{abstract}
Globalization, urbanization, digitalization, climate change create new trends in improving of the competitiveness of the national economy by acting industrial system optimization in the format of the "Industry 4.0" concept, aimed at integrating of physical operations and related processes of production systems into a single information space. However, this can not be done outside the solution of the problem of increasing the competitiveness of cities - the concentration of production systems. Energy efficiency ensuring is the main feature of production system optimizing of the new generation "Industry 4.0". The aim of the research is to reveal the potential of a new paradigm for production systems optimizing based on the "Industry 4.0" concept in the regions of Russia. The article shows historical experience and features of production system optimization based on the concept of "Industry 4.0" in the regions of Russia; practical aspects of introduction of digital technologies in production systems on the basis of "smart city" concepts aimed at resource and energy saving; the rationale of the advantages of the original local automated system for energy efficiency managing at industrial enterprises which have a high potential for introducing and stimulating of energy saving effects in the optimization of production systems.
\end{abstract}

\section{Introduction}

Nowadays, we can observe five global megatrends in the global community: climate change, demographic changes (population aging), globalization, urbanization and digitalization. About $54 \%$ of the world's population lives in cities, and by 2030 this index will increase to 66$70 \%$. At the same time, most of the energy resources and polluting substances are formed and consumed in the urban environment.

The search for answers to the question of how to develop and improve competitiveness in modern cities, in order to reduce energy consumption in the conditions of increasing urbanization and at the same time ensure environmentally friendly comfortable living of the population, is implemented by researchers in all corners of the globe [1-7]. And increasingly, as a solution to the above-mentioned problems, it is proposed to introduce elements of an "smart" city, an "smart" region.

\section{2 «Smart» city and «Industry 4.0 »}

Currently, the implementation of the concept of "smart" city is taking place during the transition to the fourth industrial revolution, called "Industry 4.0".

The first revolution began with the invention of the steam engine by James Watt and created the primary industrialization in Europe throughout the 18th and 19th centuries.

The second revolution occurred at the beginning of the 20th century with Henry Ford's invention of the assembly line, due to this, it was possible not only to create a mass market, but also to make the car available.

The third revolution began in the 1960s, when a computer was invented, and later - industrial robots (Fig. 1).

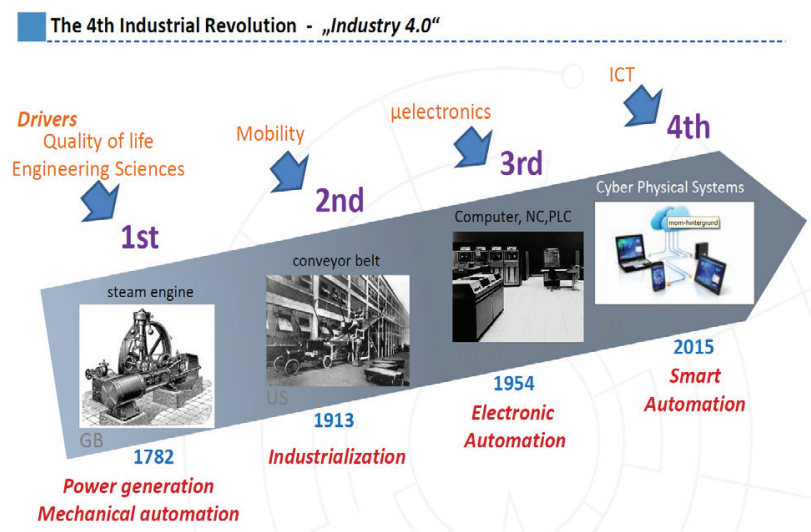

Fig. 1. Types of industrial revolutions.

Analysts at McKinsey \& Company suggest "Concept $4.0^{\prime \prime}$ as the new business processes that are being introduced in the industry in the 21 st century. At the same time, the first concept - is "thrifty" production of the 1970s, the second - the phenomenon of outsourcing production to developing countries in the 1990s, the third - the wide automation of zeroes [8].

The industrial concept "Industry 4.0 " is a global, complex, multi-level organizational and technical system based on the integration of physical operations and

\footnotetext{
* Corresponding author: tatpersh@yandex.ru
} 
related processes into a single information space consisting of 6 subsystems:

1. PLM (Product Lifecycle Management).

Complexes of object-oriented application software, also known as PLM-systems, are intended for structuring of the automation of physical and information process control throughout the entire product life cycle.

\section{Big Data .}

Big Data is a set of data of traditional and digital sources inside and outside the company. The data is collected everywhere: from sensors, company employees, counterparty companies, customers, service centers, suppliers, etc., after that, the data is structured, analyzed and used. The main task of enterprises when working with Big Data, to interpret the data for further use best way.

3. Smart Factory .

The basis of the Smart Factory concept is the connection of individual stages (operations) of the production process, from the stage of product design and planning of the production resources use to executive mechanisms. The foundation of "Smart Factory" is the concept of "Digital Manufacturing". Digital Manufacturing is an organizational and technical system of adequate production simulation, based on advanced simulators based on CAD. Today, there are several production virtualization systems, such as: DELMIA Digital Manufacturing (Dassault Systèmes); Tecnomatix (Siemens PLM Software); Factory Design Suite (Autodesk); Visual Components and others.

4. Cyber-physical systems.

Cyberphysical system is an organizational and technical concept of information flow management, integration of computing resources into physical production processes.

5. Internet of Things (IoT).

The Internet of things is a simple definition of a grandiose concept. IoT is the concept of a computer network of physical objects (things) equipped with builtin technologies to interact with each other or with the external environment, considering the organization of such networks as a phenomenon which is able to restructure economic and social processes, excluding from the part of actions and operations the need for human participation. IoT connects things that are connected to the Internet with each other and ensures their collaboration, managed by cloud computing systems.

6. Interoperability (functional compability).

Interoperability - the most important factor of the industrial concept Industry 4.0. Without functional compability, it is impossible to create an efficient integrated industrial system "Industry 4.0". High efficiency is achieved by the rational system management of automation of physical production operations and related processes integrated into a single information space.

The Industrial Internet of Things (IIoT) is a key part of the "Industry 4.0" concept and means the interconnected functioning of information and operational technologies in production. This is not just a trend, it is a real way to solve specific tasks, from operational safety to financial indexes. The industrial Internet of things is a B2B direction ("business for business"). This includes M2M solutions (machinemachine interaction), big data, cloud, robotics, etc.

Abroad, one of the directions of the strategic development of the economy is the digitization of all spheres, and mainly of industrial production. Therefore, some countries have come close to the ideal model of Industry 4.0, that is, to digitized and automated production, which, in real time without human participation, is managed by intelligent systems. These technologies are being implemented at enterprises of such global corporations as: General Electric, BASF, Boliden, Honda, Bosch, British Petroleum, Daimler, Goldcorp, Intel, Konecranes, Nestle, Coca-Cola, Osram, Potash Corporation, Pirelli, SKF, SEAT, Siemens, Akzo Nobel, The Anglo Platinum Group and others.

\section{The features of the implementation of the "Industry 4.0" concept in Russia}

Currently, Russia has a target re-equipment program (2015-2020), which implies a comprehensive modernization of state-owned enterprises, namely, the introduction of innovative technologies, the purchase of new equipment. In connection with the entry into the new phase of industrial development, questions are raised about the effectiveness of new equipment use, the recoupment of the costs and the profit increase of the enterprise are studied. Today, many Russian enterprises are modernizing, which means that there is a chance to equip production with intellectual technologies and make them technological leaders, that will make Russian-made products more competitive in the world market.

In Russia, the technologies of the Internet of things have not acquired a mass character, and the way to Industry 4.0 will not be easy, but examples of implementation in various industries have already existed (Table. 1).

Table 1. Examples of IoT implementation in Russia.

\begin{tabular}{|c|c|c|}
\hline Direction & Company & $\begin{array}{c}\text { Tasks } \\
\end{array}$ \\
\hline $\begin{array}{l}\text { System } \\
\text { integrators } \\
\text { and IT } \\
\text { services }\end{array}$ & $\begin{array}{l}\text { Technocore, } \\
\text { Sibintec, } \\
\text { Aiteko, Revolta } \\
\text { Engineering }\end{array}$ & $\begin{array}{c}\text { - selection of optimal } \\
\text { platforms } \\
\text { - development of new } \\
\text { solutions } \\
\text { - implementation of } \\
\text { technologies at enterprises }\end{array}$ \\
\hline $\begin{array}{c}\text { Information } \\
\text { security } \\
\text { systems }\end{array}$ & Kaspersky Lab & - security in IoT solutions \\
\hline $\begin{array}{l}\text { IT services } \\
\text { and Internet } \\
\text { platforms for } \\
\text { transport }\end{array}$ & $\begin{array}{c}\text { Transport TV, } \\
\text { StarLine, } \\
\text { Yandex }+ \\
\text { KAMAZ }\end{array}$ & $\begin{array}{l}\text { - production of unmanned } \\
\text { vehicles } \\
\text { - the provision of } \\
\text { information and media } \\
\text { services on public } \\
\text { transport } \\
\text { - the organization of a } \\
\text { safety system for motor } \\
\text { transport } \\
\text { - deployment of smart } \\
\text { transport infrastructure }\end{array}$ \\
\hline
\end{tabular}




\begin{tabular}{|c|c|c|}
\hline $\begin{array}{l}\text { IT solutions in } \\
\text { energy } \\
\text { industry and } \\
\text { utilities }\end{array}$ & $\begin{array}{c}\text { Prospective } \\
\text { linear } \\
\text { technologies, } \\
\text { Strizh } \\
\text { Telematics } \\
\end{array}$ & $\begin{array}{l}\text { - delivery of measuring } \\
\text { equipment and various } \\
\text { solutions for the energy } \\
\text { and utilities sector }\end{array}$ \\
\hline $\begin{array}{l}\text { IT solutions } \\
\text { for agriculture }\end{array}$ & $\begin{array}{c}\text { Neoflex, } \\
\text { Revolta } \\
\text { Engenneering }\end{array}$ & $\begin{array}{l}\text { - supply of intelligent } \\
\text { systems for optimizing } \\
\text { and improving of the } \\
\text { efficiency of agriculture }\end{array}$ \\
\hline $\begin{array}{c}\text { IT systems } \\
\text { and devices } \\
\text { for the Smart } \\
\text { Home } \\
\end{array}$ & $\begin{array}{l}\text { GS Group, } \\
\text { Aqua-care }\end{array}$ & $\begin{array}{l}\text { - development of solutions } \\
\text { for Smart Home }\end{array}$ \\
\hline Electronics & $\begin{array}{c}\text { Mikron, } \\
\text { Angstrem, T8, } \\
\text { T-Platforms }\end{array}$ & $\begin{array}{c}\text { - creation of platform } \\
\text { hardware solutions, } \\
\text { networks and } \\
\text { infrastructure for IoT } \\
\text { - supply of } \\
\text { microelectronic } \\
\text { components and sensors, } \\
\text { computers, network and } \\
\text { telecommunication } \\
\text { equipment }\end{array}$ \\
\hline Link & $\begin{array}{c}\text { MTS, } \\
\text { MegaFon, } \\
\text { Beeline, Tele2, } \\
\text { Rostelecom }\end{array}$ & $\begin{array}{c}\text { - stimulating the } \\
\text { introduction of IoT } \\
\text { technologies } \\
\text { - development of M2M } \\
\text { services }\end{array}$ \\
\hline
\end{tabular}

Source: made by authors

Digital technologies in production allow to create a single production cycle, participation in which will take only machines and mechanisms. The transition to digital production is a five-level pyramid.

Business level - EPR

Production level - MES

Technological level - CAM / CAE, PDM

Level of Design-CAD

Monitoring system - MDC

The business level is the top level - it's EPR. On the basis of the EPR system, purchase and production orders are made. The production level is the MES system, which help to create the equipment loading drawing. Technological level - study in CAM / CAE, PDM systems. Level of design - drawings and 3D model are designed in the CAD system. The monitoring system is the last base level on which everything else is built. MDC-systems increase the efficiency of production without significant investment, while solving other problems. These systems operate on the basis of monitoring protocol programs on $\mathrm{CNC}$ machines. The information received from the protocol programs is sent to the server, where it subsequently generates reports for individual services and managers. The monitoring system is the starting point of "Industry 4.0". It does not automate production fully, but with the data obtained through monitoring, a single information space of the enterprise is created. Abroad, monitoring is an indispensable object of production. In Russia, the monitoring of production is carried out by several systems: AIS «Dispatcher», developments from "Signum», «Solver», X-Tensive, etc. AIS «Dispatcher » has more than 50 implementations in large plants. Thus, data to analyze the effectiveness of MDC- systems and the first results exist, it remains to reach the mass level.

\section{Local automated energy saving management system at industrial enterprises}

At present, in the Russian Federation, one of the most important strategic purposes set by the President of the Russian Federation is the reduction by 2020 of the energy intensity of the domestic economy by $40 \%$ [9]. On the way to achieve this aim, all organizations (institutions) of business, government, society should be energy efficient. Energy audit as one of the main instruments of the movement towards energy efficiency does not allow to organize permanent monitoring and analysis of energy consumption, it is not free from errors, subjectivism of assessments and corruption schemes in implementation in connection with which alternative methods and tools of energy efficiency management at the local level are required [10] .

The analysis showed that, unfortunately, none of the existing software products do not fully match to requirements that are presented to them. For example, workplace SRO "Energypasport" allows only to fill out the energy passport and does not have any additional functions for auto-settlements, conversion etc. A more successful software product is the «E-Pass » workplace, which is designed to automate the work of energy auditors in conducting and finalizing the results of the energy survey, but it is not suitable for implementing all energy management functions at the enterprise.

Foreign software products such as AMR systems (Automatic Meter Reading), PLC (Power Line Communication), ENSI (Energy Saving International) and their localized Russian versions are also on the Russian market [11-13]. But, work with these products is only available to trained energy auditors, and there are no tools for local energy efficiency management, that is, directly at the level of organizations (institutions) and business enterprises, authorities, society.

To solve this problem, within the concept "Industry 4.0" (a subsystem of the Smart Factory), scientists from the Volgograd State Technical University developed a local automated system for managing energy efficiency at industrial enterprises [14-16].

It is based on the Firebird DBMS, which, firstly, is free for distribution and use, and secondly, is ideally suited for a combination of factors: ease of maintenance / free / speed. DBMS Firebird offers concurrency, high efficiency and powerful language support for stored procedures and triggers. It is a commercially independent project of $\mathrm{C}$ and $\mathrm{C}++$ programmers, technical advisors and supporters of the formation and strengthening of multi-platform relational database management systems, based on the source code released by Inprise Corporation (now known as Borland Software). Now we can say with certainty that FireBird is a developed industrial software that guarantees transactional data integrity when using it with multiple users that conforms to ACID rules: 
1.Atomicity - atomicness of transactions;

2.Consistency - data integrity;

3.Isolation - user access control;

4.Durability - long-term storage of data [17].

The energy efficiency management system allows analyzing the modes of operation of complex aggregates and systems, predicting their technical condition depending on specific operating conditions, planning the necessary procedures to reduce production risks, increasing the energy efficiency of fixed assets use, reducing energy production costs in terms of energy efficiency based on accumulated indicators, telemetric information.

The energy management system allows:

1) to automate the process of energy efficiency management in the enterprise;

2) to optimize the cost of energy audit, as compared with the involvement of an external energy auditor, by preventing the likelihood of technical and design errors in the filling of energy passports / declarations;

3 ) to reduce time spent on data processing and preparation of Energy Saving Programs

4) to fill in energy declarations by experts of budgetary organizations;

$5)$ to raise the qualification level of employees in the process of working with the system.

Using the software allows to make the process of registration of the survey results / filling out the energy declaration more convenient and simple, which in turn allows to reduce costs and increase the efficiency of enterprises of various forms of ownership.

As a result of approbation of the proposed automated energy efficiency management system at the enterprise of the industry, the Program of energy saving measures was developed and successfully implemented.

Table 2. The final Program of energy-saving measures of the enterprise JSC "Volzhsky Abrasive Plant".

\begin{tabular}{|c|c|c|c|}
\hline Measures & $\begin{array}{l}\text { Annual } \\
\text { economic } \\
\text { effect, } \\
\text { thous. rub. }\end{array}$ & $\begin{array}{l}\text { Payback } \\
\text { period, } \\
\text { years }\end{array}$ & $\begin{array}{l}\text { Cost of } \\
\text { measures, } \\
\text { thous. } \\
\text { rub. }\end{array}$ \\
\hline \multicolumn{4}{|c|}{ Quickly-paid measures } \\
\hline $\begin{array}{l}\text { Introduction of energy } \\
\text { management in the } \\
\text { enterprise }\end{array}$ & 525,180 & 0,75 & 395,120 \\
\hline $\begin{array}{l}\text { Replacement of } \\
\text { fluorescent lamps } \\
\text { with lamps of the } \\
\text { same standard size of } \\
\text { less power }\end{array}$ & 5,547 & 1 & 3 \\
\hline $\begin{array}{l}\text { Translation of boiler } \\
\text { houses from liquid } \\
\text { fuel to gas and use of } \\
\text { energy-saving boilers }\end{array}$ & 716,4 & 0,3 & 360 \\
\hline \multicolumn{4}{|c|}{ Medium-cost measures } \\
\hline $\begin{array}{l}\text { Installation of a } \\
\text { variable-frequency } \\
\text { drive at a compressor } \\
\text { station }\end{array}$ & 1125,378 & 2,2 & 2475,83 \\
\hline
\end{tabular}

\begin{tabular}{|l|c|c|c|}
\hline $\begin{array}{l}\text { Installation of heat } \\
\text { flow regulators }\end{array}$ & 1350 & 1,07 & 1450 \\
\hline \multicolumn{4}{|c|}{ Long-term measures } \\
\hline $\begin{array}{l}\text { Thermal insulation of } \\
\text { hot water pipelines }\end{array}$ & 73,5 & 3,7 & 270 \\
\hline $\begin{array}{l}\text { Reconstruction of } \\
\text { autoclaves }\end{array}$ & 944,784 & 3,45 & 3262 \\
\hline $\begin{array}{l}\text { Creation of the } \\
\text { infrared heating } \\
\text { system }\end{array}$ & 163,8 & 4 & 678,881 \\
\hline $\begin{array}{l}\text { Introduction of the } \\
\text { automated system of } \\
\text { commercial electricity } \\
\text { metering }\end{array}$ & 439,59 & 3,25 & 1430 \\
\hline TOTAL & 5344,179 & & 10324,8 \\
\hline
\end{tabular}

The final Program of energy-saving measures is designed for a long-term period. It is planned to receive profit already for the first year in the amount of 5344.179 thousand rubles with a total cost of 10324.832 thousand rubles. In the future, it is also planned to receive profit in this amount depending on the payback period of energy-saving measures.

It should be noted that some measures not only save energy costs, but also have a positive impact on the environmental situation, which, if possible, should be reflected in the final indicators.

At the enterprise JSC "Volzhsky Abrasive Plant" according to the forecast before the implementation of the project of the energy efficiency increase and implementation of the Program of energy-saving measures, energy costs in the cost structure by the end of 2017 will amount to 129107 thousand rubles, and according to the forecast after the Program will amount 122522,543 thousand rub. Thus, the reduction of energy costs in the structure of the cost of production and services of JSC "Volzhsky Abrasive Plant" due to the introduction of the proposed measures will amount $5.1 \%$.

The real dynamics of electricity prices, real disposable income of the population may turn out to be somewhat different due to the inevitable error (uncertainty) of the used initial data and some unaccounted factors (including options for reforming the electric power industry and housing and communal services).

\section{The analysis of factors hindering the implementation of the concept «Industry $4.0 »$ in domestic enterprises}

As shown by the analysis, the introduction of the concept of "Industry 4.0" at industrial enterprises in Russia is very late. This process is inhibited by a number of factors:

1. Economic factors:

- lack of own funds;

- high cost of innovation.

2. Production factors:

- low innovative potential of the company;

- lack of qualified personnel; 
- the susceptibility of the company to innovation.

An essential advantage of resolving production factors is that technologies of "Industry $4.0^{\text {" can be }}$ implemented in stages. Individual intellectual elements allow to modernize existing production assets, gradually bringing them closer to the standards of the future. Starting with individual units, it is possible to gradually transform the whole industrial enterprise. To implement the program for the introduction of industrial Internet and the transition to "Industry 4.0", it is necessary to implement retraining of the managerial personnel and senior management. Because for the effective management of enterprises operating on the basis of "Industry 4.0", absolutely new management skills are required in comparison with the management of traditional enterprises. This approach minimizes the amount of time which is necessary for the enterprise to transit to "Industry 4.0 ".

In addition to the re-qualification of the company's managers, new knowledge and skills will be required from the engineering department. For this, the training programs that are being used now will have to be radically changed, putting training in programming and teaching IT technologies at the equal level with the profile training. For effective work at the enterprise working on the basis of "Industry 4.0", knowledge of programming languages will be required in order to intervene in the workflow of digital production in a timely manner. These requirements will give impetus to the educational sphere, which will entail the training and retraining of existing workforce, on the basis of newly opened centers of excellence. But in addition to the positive moment in the concept of "Industry 4.0 ", there is also a negative point, that full automation of the technological process in production will entail a massive reduction of workplaces.

It is clear that to implement the "Industry 4.0", the company's own funds are not enough. To do this, it is necessary to resort to borrowed funds. Sberbank provides a loan "Financing of investment projects", aimed at the reconstruction, modernization, existing production. Also an effective tool for financing new production projects of Russian enterprises is the Production Development Fund, as well as the Fund for the Development of Internet Initiatives.

\section{Conclusion}

The received scientific results have a practical focus and can be applied in the process of developing and implementing of energy conservation policies aimed at the formation and effective implementation of the energy saving potential of industrial enterprises and companies.

\section{References}

1. C.A. Jenne, R.K. Cattell, Energy Economics, 5, 114 (1983)

2. M. Marques, R. Neves-Silva, Journal of Cleaner Production, 88, 115 (2015)
3. Y. Kim, A. Aravkin, H. Fei, A. Zondervan, and M. Wolf, IBM Journal of Research and Development, 1 (2016)

4. V. Blass, C.J. Corbett, M.A. Delmas and S. Muthulingam, Energy, 65, 560 (2014)

5. V.U. Baldin, N.I. Danilov, G.I. Khudyakova, WIT Transactions on Ecology and the Environment, 2, 1208 (2014)

6. G.J. Tsekouras, M.A. Tsaroucha, C.D. Tsirekis, A.D. Salis, E.N. Dialynas and N.D. Hatziargyriou, International Journal of Electrical Power and Energy Systems, 6, 1222 (2011)

7. S. Rajabi, S. Behairy, Procedia Engineering, 1088 (2016)

8. S. Bouton, D. Cis, L. Mendonca and etc. Annual report McKinsey \& Company, (2013)

9. M. Belyaev, O. Maksimchuk, O. and T. Pershina, Management of energy consumption in the enterprises of housing and communal economy. Volgograd: VolgGASU.144 (2009)

10. S. Gheorghe, N. Golovanov, H. Albert, C. Stanescu and D. Ilisiu, Proceedings of International Conference on Harmonics and Quality of Power, ICHQP, 430 (2014)

11. A.G. Van Engelen, J.S. Collins, Proceedings of the Annual Hawaii International Conference on System Sciences (2010)

12. A. Al-Mofleh, S. Taib, H. Al-Gulman, Proceeding of the 5th International Symposium on Mechatronics and its Applications (2008)

13. R. Hackl, E. Andersson, S. Harvey, Chemical Engineering Transactions, 21, 301 (2010)

14. O. Maksimchuk, T. Pershina, G. Golikova, N. Borisova, N. and S. Ivashova, The concept of energy saving management in housing and communal services: a systematic approach. Volgograd: Crouton.284 (2015).

15. T. A. Pershina, The system development of the energy expenses management in the enterprises of housing and communal services. Volgograd.174 (2006)

16. T. A. Pershina, Journal of Volgograd State University, 7, 133 (2008)

17. H. Borry, FireBird. Guide Database Developer. St. Petersburg : BHV-Petersburg.104 (2006) 